\title{
Water Quality of Nimrud District Wells Southeast of Mosul City for Drinking and Civil Purpose Using the Canadian Model of Water Quality
}

\author{
Abdul-Aziz Y. T. Al-Saffawi \\ Department of Bio., Coll. of Education for Pure Science, University of Mosul, Iraq. \\ Corresponding Author Email: alsffawia65@gmail.com \\ Received 06 September 2018, Revised 15 February 2019, Accepted 30 June 2019
}

\begin{abstract}
The current study aims at determining the water quality of the Nimrud district wells, southwest of Mosul, for drinking and civilian purposes by using the Canadian model of water quality. The aquatic samples were collected from randomly distributed wells in the area during the dry season for chemical and physical testing to assess their quality. The results of the study indicated the high levels of most of the studied characteristics, which reflected negatively on the values of CCME WQI (Canadian Council of Ministers of the Environmental Water Quality Index), where 70\% of them classified as poor quality water for drinking and domestic use. The study recommended periodic monitoring of the quality of water with water treatment processes before being used for drinking.
\end{abstract}

Keyword: CCME WQI, Groundwater quality, Nimrud district

\section{Introduction}

The provision of adequate water for human use has become one of the most difficult problems in many regions of the world, especially in the third world countries. Large numbers of human diseases are transmitted by water and cause various serious diseases, which may cause death such as cholera, typhoid, dysentery, amygdala, viral hepatitis, poliomyelitis, shigellosis, etc [1]. Studies in developing countries indicated that more than 875 million diarrhea cases occur every year, with 3 million deaths due to the use of unsafe drinking water that leads to diarrheal diseases specially in children [2]. For example, many African people suffer from lack of clean water. 18 million people in Kenya and 57 million in Nigeria do not have access to clean water. More than 3,100 children in Kenya and 45,000 children in Nigeria die every year from diarrhea caused by contaminated [3].

The truth is terrifying according to UNEP (United Nations Environment Program) predictions
[4] that two-thirds of the world's population will suffer from water shortages by the year 2025, including 25 countries in Africa alone. The continued environmental deterioration may lead to a disaster that is difficult to overcome. Therefore, the international public opinion has stimulated the concerns of increasing water pollution and decreasing its amounts with increased community. Thus, awareness is recommended by all means of information. Especially, in developing countries, including Iraq with the activation of the role of environmental laws. The periodic inspection and controls of water resources are encouraged. The tracking of pollution sources to reduce deterioration of water is very important. Also, the trend towards rationalization of water consumption in all areas to maintain this wealth with the use of modern methods for estimating water quality, such as using mathematical models to assess the surface and groundwater quality should be taken into account. 
The use of WQI models of water quality was widely spread after the introduction of a mathematical model by Horton in 1965, which was later developed by Brown in 1970 [5, 6]. Over time, a large number of models have been proposed and developed because of the evidence's ability to give a single value that reflects the interferences between large numbers of data and water characteristics which are understood by all [7,8]. Some models, such as CCME WQI, WAWQI, the National Sanitation Foundation (NSFWQI) and the OWQI OWQI are among the most widely used and popular models in the world [8]. The CCME WQI model is widely used worldwide by researchers to evaluate water sources and determine the degree of contamination. This model is concerned with the weight of the parameters, which is a deviation of even one test from the standard limits, but also to the weight of each measurement (test value) deviated from the standard limits, which gives high precision in the assessment of water quality studied [9-11]. Therefore, the study was conducted with the aim of assessing the groundwater of Al Nimrud district for drinking purposes using the Canadian Model.

\section{Materials \& Methods}

Study site: Some physical and chemical properties of groundwater sources were studied in Al-Nimrud district, Nineveh governorate, southeaste of Mosul city, along with latitude (36 $\left.10^{`} \mathrm{~N}\right)$ and longitude (43 20E). Ten wells were identified randomly, as shown in Fig. 1 and most of them are unpalatable and of bitter taste because the geological formations of the study area are characterized by the formation of Al-Fatha (lower Faris) containing the evaporated salts, gypsum, anhydrite, limestone, etc., leading to deterioration of the quality of water $[12,13]$.

Water sampling: Forty-four water samples (during the dry season) were collected using clean polyethylene bottles for physical and chemical measurements according to internationally approved analysis methods [14].

Methodology: The acid function was measured by the $\mathrm{pH}$ meter after regulating the device with multiple buffer solutions having $\mathrm{pH} \mathrm{9,7}$ and 4 .
Total dissolved solids were determined by evaporating filterable water samples; the obtained residue was further dried at $105{ }^{\circ} \mathrm{C}$. Total hardness, calcium and magnesium were measured by EDTA titration methods [14, 15]. Total alkalinity was determined by titration with sulfuric acid using methyl orange and phenolphthalein as indicators, also chloride by silver nitrate titrimetric method ( Mhor M.). Amounts of sodium and potassium were evaluated with the Flame photometer. Sulfate ions were determined by Turbidimatric M. and Nitrate was measured by Ultraviolet screening M test.

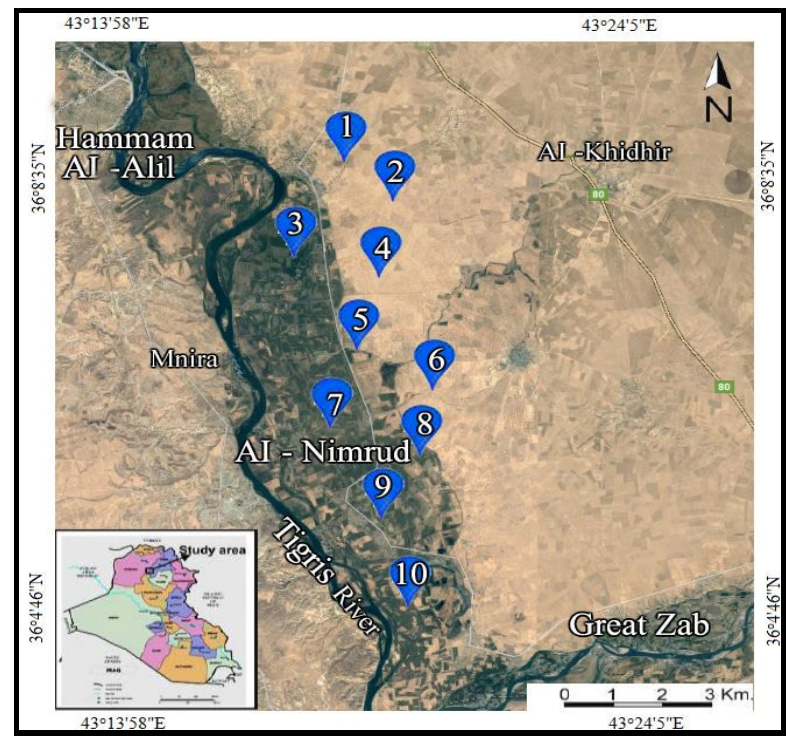

Figure 1. Map of the southern part of Iraq (Nineveh governorate) showing the studied stations.

\section{Calculation of the Canadian Water Quality Index}

The Canadian Mathematical Model of Water Quality is characterized by high accuracy and the values of the index are calculated by three factors as follows [16-18].

1. (Scope) $\mathrm{K}_{1}$ : represents the percentage of variables exceeding standard limits compared to the total number of variables (even once during the study period.

$\mathrm{K}_{1}=\left[\frac{\text { Number of failed variables }}{\text { Total number of variable }}\right] \times 100$ 
2. (Frequency) $\mathrm{K}_{2:}$ Percentage of individual tests exceeding standard limits on the total number of tests.

$\mathrm{K}_{2}=\left[\frac{\text { Number of failed variables }}{\text { Total number of tests }}\right] \times 100$

3. (Amplitude) $\mathrm{K}_{3}$ : The number of exceeded tests were calculated in three stage:

The first stage: the number of times the individual concentrations of the standard limits exceeded (called the excursion) was calculated as follows:

a. When the test value must not exceed the objective:

Excursion $=\left[\frac{\text { Failed test caluei }}{\text { Objective } \mathrm{j}}\right]-1$

b. When the test value must not fall below the objective:

Excursion $=\left[\frac{\text { Objective } \mathrm{j}}{\text { Failed test caluei }}\right]-1$

The second stage: the quantity of the group of individual exceeded tests calculated by divided the sum of individual deviations and divided on the total number of tests and called Normalization of Excursion:

nse $=\frac{\sum_{\mathrm{i}}^{\mathrm{n}}=1 \text { excusion }}{\text { Number of Test }}$

The third stage: calculation of $F_{3}$ by the following equation:

$\mathrm{K}_{3}=\left[\frac{\mathrm{nse}}{0.01 \mathrm{nse}+0.01}\right]-1$

Finally the CCME WQI is calculated as:
$\mathrm{CWQ}_{1}=100-\left[\frac{\sqrt{\mathrm{K}_{1}^{2}+\mathrm{K}_{2}^{2}+\mathrm{K}_{3}^{2}}}{1} .732\right]$

Constant 1.732 is to modify the result of the index value and makes it limited between 0.0 100. Then water quality index values are classified into five categories as shown in (Table 1).

Table 1. Classification of water quality based on values of CCME WQI [19].

\begin{tabular}{|l|l|l|l|l|l|}
\hline WQI value & $95-100$ & $80-94$ & $65-79$ & $45-64$ & $0-44$ \\
\hline Categories & Excellent & Good & Fair & Marginal & Poor \\
\hline Class & 1 & 2 & 3 & 4 & 5 \\
\hline
\end{tabular}

\section{Results and Discussion}

In the present study, the physiochemical analysis results of groundwater, which was collected from ten wells of Al-Nimrud district are presented. The guideline values (objectives), recommended by Iraqi standards $[19,20]$ are listed in (Table 2).

The values of the various scopes $\left(\mathrm{K}_{1}\right)$, frequencies $\left(\mathrm{K}_{2}\right)$, and amplitudes $\left(\mathrm{K}_{3}\right)$, with their respective WQI, are presented in (Table 3). During the study period, the CCME WQI values of the groundwater at the wells showed that the water can be ranked from 21 to 62 . The WQI values were relatively lower; however, these values revealed that the groundwater quality could be ranked as marginal at the wells 3, 5, 9 for drinking and domestic uses. However, the values obtained for remaining wells were lower than 38 making the water to be ranked as poor quality water.

The decrease in WQI values is an evident that different pollutants are present in the groundwater due to the their geological formation; that is Al-Fatha (Lower Fars) that consists mainly of gypsum, anhydrite, evaporated salts limestone. Moreover, various agricultural activities may be accountable for the poor water quality [21]. 
Table 2. The physiochemical analysis results parameters of the groundwater $(\mathrm{mg} / \mathrm{L})$.

\begin{tabular}{|c|c|c|c|c|c|c|c|c|c|c|c|c|}
\hline \multicolumn{2}{|c|}{ Well No. } & \multirow{2}{*}{$\begin{array}{l}\mathbf{p H} \\
6.55\end{array}$} & \multirow{2}{*}{$\begin{array}{l}\text { TDS } \\
4198\end{array}$} & \multirow{2}{*}{$\begin{array}{c}\text { T.alk. } \\
244\end{array}$} & \multirow{2}{*}{$\begin{array}{c}\text { T.H } \\
2280\end{array}$} & \multirow{2}{*}{$\begin{array}{c}\mathbf{C a} \\
389\end{array}$} & \multirow{2}{*}{$\begin{array}{l}\mathbf{M g} \\
256\end{array}$} & \multirow{2}{*}{$\begin{array}{l}\mathrm{Na} \\
365\end{array}$} & \multirow{2}{*}{$\begin{array}{c}\mathbf{K} \\
4.0\end{array}$} & \multirow{2}{*}{$\begin{array}{c}\mathbf{C l} \\
356\end{array}$} & \multirow{2}{*}{$\begin{array}{l}\mathbf{S O}_{4} \\
1166\end{array}$} & \multirow{2}{*}{$\frac{\mathrm{NO}_{3}}{1.3}$} \\
\hline & Min. & & & & & & & & & & & \\
\hline 1 & Max. & 7.24 & 5144 & 496 & 2720 & 569 & 321 & 495 & 9.0 & 465 & 1523 & 10.6 \\
\hline & mean & 6.89 & 4818 & 326 & 2473 & 514 & 293 & 440 & 7.0 & 406 & 1328 & 5.2 \\
\hline \multirow{3}{*}{2} & Min. & 6.89 & 4898 & 247 & 2330 & 409 & 246 & 418 & 50 & 296 & 1253 & 2.1 \\
\hline & $\operatorname{Max}$ & 7.10 & 5144 & 566 & 2440 & 545 & 340 & 510 & 115 & 328 & 1309 & 19.0 \\
\hline & mean & ---- & 4997 & 348 & 2390 & 505 & 275 & 459 & 63 & 315 & 1371 & 9.3 \\
\hline \multirow{3}{*}{3} & Min. & 7.5 & 1488 & 130 & 850 & 96 & 78 & 96 & 3.6 & 170 & 393 & 1.1 \\
\hline & $\operatorname{Max}$ & 7.6 & 1536 & 286 & 980 & 224 & 156 & 141 & 4.0 & 196 & 544 & 6.2 \\
\hline & mean & --.- & 1507 & 187 & 903 & 152 & 119 & 123 & 3.9 & 181 & 467 & 4.5 \\
\hline \multirow{3}{*}{4} & Min. & 6.73 & 3954 & 216 & 980 & 152 & 146 & 249 & 28 & 260 & 889 & 1.7 \\
\hline & Max. & 7.28 & 4064 & 644 & 1900 & 409 & 285 & 475 & 50 & 318 & 1438 & 12.9 \\
\hline & mean & ---- & 4001 & 384 & 1600 & 87 & 222 & 333 & 39.0 & 289 & 1147 & 7.7 \\
\hline \multirow{3}{*}{5} & Min. & 7.30 & 1392 & 165 & 1070 & 44 & 83 & 229 & 4.0 & 140 & 636 & 1.3 \\
\hline & Max. & 7.53 & 2444 & 314 & 740 & 514 & 153 & 613 & 23.0 & 325 & 1049 & 5.4 \\
\hline & mean & --- & 2073 & 225 & 2720 & 87 & 123 & 378 & 11.3 & 273 & 916 & 3.4 \\
\hline \multirow{3}{*}{6} & Min. & 7.53 & 3314 & 139 & 1060 & 128 & 156 & 547 & 6.4 & 445 & 1370 & 1.2 \\
\hline & Max. & 7.68 & 3572 & 262 & 1250 & 200 & 226 & 820 & 9.1 & 543 & 1645 & 5.9 \\
\hline & mean & ---- & 3441 & 179 & 1178 & 173 & 181 & 664 & 7.8 & 498 & 1470 & 3.3 \\
\hline \multirow{3}{*}{7} & Min. & 6.71 & 2322 & 188 & 1100 & 80 & 146 & 415 & 5.3 & 286 & 786 & 1.1 \\
\hline & Max. & 7.52 & 2472 & 370 & 1780 & 385 & 204 & 487 & 9.1 & 330 & 1297 & 6.3 \\
\hline & mean & ---- & 2439 & 283 & 1255 & 208 & 179 & 461 & 7.5 & 311 & 1098 & 4.0 \\
\hline \multirow{3}{*}{8} & Min. & 6.7 & 1738 & 355 & 2280 & 241 & 353 & 113 & 9.0 & 378 & 1355 & 2.7 \\
\hline & Max. & 7.32 & 5782 & 644 & 2340 & 357 & 423 & 820 & 13.0 & 420 & 1865 & 9.5 \\
\hline & mean & ---- & 4243 & 454 & 2320 & 302 & 381 & 553 & 11.0 & 396 & 1688 & 6.8 \\
\hline \multirow{3}{*}{9} & Min. & 7.20 & 1340 & 120 & 1060 & 152 & 102 & 104 & 1.2 & 120 & 527 & 10.3 \\
\hline & $\operatorname{Max}$ & 7.32 & 1806 & 126 & 1080 & 265 & 165 & 113 & 1.7 & 128 & 578 & 11.3 \\
\hline & mean & --- & 1573 & 123 & 1070 & 159 & 134 & 109 & 1.3 & 124 & 553 & 10.8 \\
\hline \multirow{3}{*}{10} & Min. & 7.30 & 1496 & 143 & 780 & 92 & 138 & 182 & 3.0 & 165 & 875 & 6.8 \\
\hline & Max. & 7.72 & 3395 & 482 & 2600 & 469 & 348 & 510 & 5.0 & 438 & 1225 & 8.9 \\
\hline & mean & ---- & 2446 & 313 & 1690 & 281 & 243 & 346 & 4.0 & 303 & 1049 & 7.9 \\
\hline \multicolumn{2}{|c|}{ Standard limit } & $6.5-9$ & 1000 & 150 & 500 & 200 & 150 & 200 & 12 & 250 & 400 & 45 \\
\hline
\end{tabular}

Table 3. Water quality index at each well.

\begin{tabular}{cccccccccccccc}
\hline Well & $\mathbf{K}_{\mathbf{1}}$ & $\mathbf{K}_{\mathbf{2}}$ & $\mathbf{K}_{\mathbf{3}}$ & WQI & Ranking & Well & K1 & K2 & K3 & WQI & Ranking \\
\hline 1. & 90 & 82 & 6.0 & 21 & Poor & 6. & 70 & 65 & 51 & 38 & \\
2. & 90 & 83 & 61 & 21 & Poor & 7. & 80 & 70 & 43 & 34 & Poor \\
3. & 60 & 37 & 15 & 59 & Marginal & 8. & 80 & 77 & 63 & 27 & Poor & \\
4. & 80 & 75 & 51 & 30 & Poor & 9. & 50 & 40 & 19 & 62 & Marginal \\
5. & 70 & 60 & 33 & 44 & Marginal & 10. & 80 & 55 & 48 & 38 & Poor \\
\hline
\end{tabular}

Thus, the results of the current study of water quality index clearly indicate that the state of most of the groundwater in the study area is not suitable for human use.

The value of $\mathrm{pH}$ has an impact on the quality of irrigation and drinking water because of its effect on the balance of carbonates and water content of mineral elements [22]. The results shown in Table 3 indicate the relative fluctuation of $\mathrm{pH}$ values ranging between $6.55-7.72$ and $77 \%$ of the water samples were within slightly alkaline range due to the presence of bicarbonate ions [14]. The low values of $\mathrm{pH}$ were may be due to the high concentration of salts, chloride and sulphurous phase at the expense of the bicarbonate phase, resulting in slightly acidic $\mathrm{pH}$ values [23]. This resulted in increased solubility of toxic mineral elements in rocks when the water passed through the geological formation and thus increased the negative effects on the consumer of this water [23]. 
All values are generally within the permissible drinking limits of WHO [20].

Total dissolved solids are important components of water and are a measure of water salinity [24]. The obtained results of TDS (Table 3) indicate that the concentrations of TDS for the studied water ranged between 1340 - 5782 $\mathrm{mgL}^{-1}$, these high concentrations are the indicator of excessive dissolution of rock minerals and salts [16]. These results are similar to the results obtained by Al-Saffawi [25] when he studied the groundwater of Al-Conseya village, Hamidat subdistrict, which had TDS value of to $2944 \mathrm{mgL}^{-1}$ and relatively larger than the results obtained for the groundwater of Al-Kubah and Al-Sherkhan areas north-west of Mosul city, which had TDS value of $2112 \mathrm{mgL}^{-1}$. In general, all studied samples exceeded the upper limits set for drinking water [20, 26].

The total alkalinity plays an important role in acid neutralization (ANC) as it minimizes the negative effects of acidic water on aquatic ecosystem [27]. In general, total alkalinity ranged between $126-644 \mathrm{mgL}^{-1}$ and $79 \%$ of the tested sample were found to have higher values than the permissible limit (Table 3 ). This relatively high concentration is due to the reactions occurring in the water when it passes through the geological formations as shown in the equations below [28]:

$$
\begin{aligned}
& \mathrm{CO}_{2}+\mathrm{H}_{2} \mathrm{O} \rightarrow \mathrm{H}_{2} \mathrm{CO}_{3} \\
& \mathrm{CaCO}_{3}+2 \mathrm{H}_{2} \mathrm{CO}_{3} \rightarrow \mathrm{Ca}\left(\mathrm{HCO}_{3}\right)_{2}
\end{aligned}
$$

The total hardness of water plays a protective role to reduce the toxic effects of some toxic substances such as heavy metals. This effect increases by increasing its concentration, as toxic elements compete on absorption sites [9].

The results obtained by groundwater surveys conducted in this investigation revealed that average of total hardness is varied between $690-2720 \mathrm{mgL}^{-1}$. The values obtained were beyond the maximum permissible level recommended by the WHO for drinking water [20]. This increase in concentration is due to the dissolution of minerals from the rocks in the geological formations [16]. The mean concentrations of calcium and magnesium were ranged between 87-514 and 119$381 \mathrm{mgL}^{-1}$, respectively.

It is useful to mention that, in all parts of Iraq $\mathrm{Na}^{+1}$ ions concentration is greater than $\mathrm{K}^{+1}$ ions. In these groundwater samples sodium and potassium concentrations reached to 820 and 115 $\mathrm{mgL}^{-1}$, respectively. These variations are due to the high solubility if sodium ions in water and potassium ions adsorption ability on the soil via ion exchange mechanism. However, $77 \%$ of tested samples often contained higher concentration of $\mathrm{Na}^{+1}$ may not be suitable for domestic and livestock purposes [29]. Determination of total chlorides is an important parameter in assessing the water quality. Chlorides have high affinity towards sodium and hence their concentration is high in groundwater due to the geothermal gradient. Soil porosity and permeability plays a key role in building up the chloride concentration. High concentration of chloride makes water unpalatable and unsuitable for drinking and livestock watering [21]. However, the mean concentration of total chlorides in the samples is varied from $124-498 \mathrm{mgL}^{-1}$. Also, it was found that $79 \%$ of tested samples exceeded from the permissible limit of chlorides that is $250 \mathrm{mgL}^{-1}$.

High concentrations of sulfate ions give water a bitter taste and causes diarrhea, especially in the presence of magnesium ions. They are naturally occurring anion present in all kinds of natural water bodies [30]. The sulfate ions concentrations in the present study were varied from $393-1865 \mathrm{mgL}^{-1}$ and the results indicated that $97 \%$ of studies samples were exceeding from the acceptable limit of sulfate ions concentration (400 $\mathrm{mgL}^{-1}$ ) recommended by the WHO for drinking water. The high concentration of nitrates is a serious threat to human health. The high amounts of nitrates in drinking water cause Blue baby syndrome especially in rural areas that use groundwater as a major source of drinking water. In addition, studies indicated their relationship with the occurrence of tumors such as cancers of the stomach, rectum, colon, and liver. Also, they cause abortiont and sudden death at the time of births [31]. Fortunately, the concentration of nitrates in the studied samples did not exceed the permissible drinking limits $\left(50 \mathrm{mgL}^{-1}\right)$, which ranged between 1.1 and $19.0 \mathrm{mgL}^{-1}$. 


\section{Conclusion}

This study suggests that the groundwater quality of the Al- Nimrud district is affected by high salinity, total hardness, sulfates, chlorides etc. due to the geological formation of the studied area. Their values exceeded greatly from the standard limits set by WHO. Also $70 \%$ of WQI values of the studied area revealed that under study samples were poor for drinking purpose. So, there is great need to control and conduct periodic tests of water quality in order to determine emergency cases. Moreover, an extensive treatment of this water is required before using it for drinking purpose [32].

\section{References}

1. O. M. Ramadhan, A. Y. T. Al-Saffawi and M. H. S. Al-Mashhdany, Int. J. Enhanced Res. Sci., Tech. Eng., 7 (2018) 63. https://www.researchgate.net/profile/Abdula ziz Al-

Saffawi/publication/328465760_Assessment _of_Surface_Water_Quality_for_Irrigation_ using_WQI_model_A_Case_Study_of_Khos ar_and_Tigris_Rivers/links/5bcf6ddf458515 2b144faabe.pdf

2. A. Y. T. Al-Safawi and A. T. H. AlMathaadi, J. Educ. Sci. Pure Sci., 27 (2018) 18.

3. A. Y. T. Al-Saffawi, J. Al-Rafidain Sci,, 27 (2018) 193.

https://iasj.net/iasj?func=fulltext\&aId $=154216$

4. UNEP, (2008). An Overview of the State of the World's Fresh and Marine Waters - 2nd Edition - 2008 [online] [Accessed April 15 2015]. Available at:

http://www.unep.org/dewa/vitalwater/article 186.html.

5. A. Y. H. Kaplan, I. O. Saeed and A. Y. T. Al-Saffawi, Alutroha Environ. Sci., 6 (2018) 45.

https://alutroha.com/

6. A. U. Farouq, J. Environ. Sci., Toxic. Food Techn., 12 (2018) 82.

http://www.iosrjournals.org/iosr-jestft.html

7. G. Krishan, S. Singh, C. P. Kumar, P. K. Garg, S. Gurjar, N. C. Ghosh and A. Chaudhary, Hydrol. Current. Res.,7 (2016) 1. doi: 10.4172/2157-7587.1000227
8. A. Y. T. Al-Saffawi, W. A. Al-Sinjari and Y. A. J. Al-Taee, Int. J. Enhanced Res. Sci., Techno. Engin., 7 (2018) 1.

https://www.researchgate.net/profile/Abdula ziz Al-

Saffawi/publication/327832446_.pdf?origin= publication_detail

9. A. Y. T. Alsaffawi, Al-utroha J. Environ. Sci., 5 (2018) 13.

https://alutroha.com/

10. A. Usman, K. Dube, K. P. Shukla, P. Salaskar, C. P. B. Prakash, P. B. Sawant and R. Singh, Int. J. Curr. Microbiol. App. Sci., 7 (2018) 520.

https://doi.org/10.20546/ijcmas.2018.704.061

11. M. D. Serajuddin, A. I. Chowdhury, E. Haque and T. Ferdous, Global Sci. Tech. J. 6 (2018) 1.

http://www.gstjpapers.com/cgisys/suspendedpage.cgi

12. N. M. Al-Sardar, A. Y. T. Al-Saffawi and R. A. A. Al-Shanona, J. Environ. Studies, [JES]. (2018).

13. A. Y. T. Al-Saffawi and Y. M. Al-Molaa, Int. J. Enhanced Res. Sci., Tech. Eng. 7 (2018) 76.

http://www.erpublications.com/uploaded_file s/download/abdul-aziz-y-t-al-saffawi-younist-m-alshuuchi-iraq_hXeHE.pdf

14. APHA, A.WWA and WCPE. (1998). "Standard method for examination ofwater and wastewater". 20th ed., Washington, DC, USA.

https://www.awwa.org/store/productdetail.as px?productid $=28493774$

15. APHA, AWWA and WCPE (2017). "Stand Method for Examination of water and wastewater American public Health Association, $23^{\mathrm{RD}}$ ed., Washington DC, USA. https://www.standardmethods.org/

16. A. Y. T. Al-Saffawi, Mesopo. Environ. J. Special Issue., (2018) 75.

17. S. A. M. Zeid, E. M. Seleem, S. A. Salman, and M. A. Abdel-Hafiz, J. Mater. Environ. Sci., 9 (2018) 1957.

https://www.jmaterenvironsci.com/Documen t/vol9/vol9 N7/216-JMES-3678-Zeid.pdf

18. A. S. Keraga, Z. Kiflie and A. N. Engida, Int. J. Water Res. Environ. Eng., 9 (2017) 243. doi: 10.5897/IJWREE2017.0736 
19. W. T. Al-Mayah and A. Mashaanrabee, J. Global Pharma Tech., 10 (2018) 196. https://www.jgpt.co.in/index.php/jgpt/article/ view/1138/845

20. WHO. (2004). Guidelines for Drinking-water Quality. Third Edition Volume 1:. World Health Organization, Geneva.

https://www.who.int/water sanitation health /dwq/GDWQ2004web.

21. A. Y. T. Al-Saffawi and N. M. S. Al-Sardar, Int. J. Enhanced Res. Sci. Tech. Eng., 7 (2018) 6.

https://www.researchgate.net/profile/Abdula ziz_Al-

Saffawi/publication/327832446_Assessment _of_groundwater_quality_status_by_using water quality index in $\mathrm{Abu}-$

Jarboaa_and_AlDarrawesh_Villages_Basiqa _subdistrict_Iraq/links/5ba79797a6fdccd3cb 6d1883/.pdf

22. A. Y. T. Al-Saffawi, R. A. A. Al-Shanona, The proceeding of the $2^{\text {ed }}$ Scientific Environmental Confer. Univ. of Mosul. Iraq. (2013) 137.

https://postconflict.unep.ch/publications/Iraq/ $\underline{\text { Iraq\%20Technical\%20Note_September2017. }}$ pdf

23. N. M. S. Al-Sardar, A. Y. T. Al-Saffawi and R. A. A. Al-Shanona, J. Educt. Sci. Pure Sci., 27 (2018) 81.
24. A. Y. T. Al-Saffawi and A. Y. Al-Assaff, J. Educat. Sci. Pure Sci., 27 (2014) 71.

25. A. Y. T. Al-Saffawi, J. Educat. Sci. Pure Sci., 20 (2007) 191.

26. A. Y. T. Al-Saffawi, F. H. Ali, and A. M. A. Kanna, The proceeding of the $6^{\text {th }}$ period. Sci. Confer. for Dam \& Water Res. Center. Mosul Univ. Iraq., (2008) 36.

27. W. E. A. Al-Sinjari, and A. Y. T. Al-Saffawi, Mesopo. Environ. J. Special Issue., (2018) 132.

28. A. Y. T. Al-Saffawi and R. A. Talaat, $J$. Rafidain Sci., 27 (2018) 181. https://www.iasj.net/iasj?func=fulltext\&aId= 154215

29. N. B. Chauhan and F. J. A. Thakor, Asian J. Exp. Biol. Sci., 3 (2012) 582. https://www.cabdirect.org/cabdirect/abstract/ 20123276810

30. A. Y. T. Al-Saffawi, and A. T. H. AlMaathidi, J. Environ. Stud., [JES]. 12 (2013) 55.

31. M. Nujic and M. H. Stanic, J. Nutr. Diet., 6 (2017) 48.

file:///C:/Users/HP/Downloads/rad_nujic.pdf

32. A. Y. T. Al-Saffawi and N. M. S. Al-Sardar, J. Educ. Sci. Pure Sci., 27 (2018) 47. 